\title{
The Conflict of Jurisdiction Between the Sending State of Foreign Military Presence and the International Criminal Court: Taking the Situation in Afghanistan as an Example
}

\author{
Fang Ruian \\ International Law School, East China University of Political Science and Law (ECUPL), Shanghai, China \\ Email address: \\ fangruian@hotmail.com \\ To cite this article: \\ Fang Ruian. The Conflict of Jurisdiction Between the Sending State of Foreign Military Presence and the International Criminal Court: \\ Taking the Situation in Afghanistan as an Example. Humanities and Social Sciences. Vol. 8, No. 4, 2020, pp. 152-160. \\ doi: $10.11648 /$ j.hss.20200805.14
}

Received: August 21, 2020; Accepted: September 14, 2020; Published: September 24, 2020

\begin{abstract}
In March 2020, the Appeal Chamber of the International Criminal Court formally authorized the Office of Prosecutor to investigate the situation in Afghanistan, and the most concern of the situation was the international crimes committed by the US military in Afghanistan. The International Criminal Court has been subject to disputes over the exercise of jurisdiction over non-parties in the United States, and in accordance with customary international law, military personnel enjoy Immunity Ratione Materiae in foreign courts, and in the case of Afghanistan, there is exclusive criminal jurisdiction granted to the United States by the US-Afghanistan bilateral Status of Forces Agreement, So that the jurisdiction of the United States and the International Criminal Court may conflict. Although military personnel's criminal immunity may be able to adjust to the jurisdiction of the International Criminal Court, when exclusive criminal jurisdiction based on bilateral treaties conflicts with the jurisdiction of an international court based on a multilateral convention, the Rome Statute, the International Criminal Court need to rely on treaty interpretation and treaty conflicts to solve the issue of jurisdiction.
\end{abstract}

Keywords: International Criminal Court, Immunity Ratione Materiae, Status of Forces Agreement, Treaty Conflict, Admissibility

\section{Introduction}

On March 5, 2020 local time in The Hague, the Appeal Chamber of the International Criminal Court ("ICC") decided unanimously to authorize the Prosecutor to commence an investigation into alleged crimes under the jurisdiction of the Court in relation to the situation in the Islamic Republic of Afghanistan. This means that the Office of the Prosecutor of the ICC will initiate a formal investigation into the international crimes committed by the US military in Afghanistan, and it is very likely to be formally prosecuted in the future. The situation has experienced several twists and turns. Prior to this, on April 12, 2019, the Pre-Trial Chamber made a decision that notwithstanding the fact all the relevant requirements are met as regards both jurisdiction and admissibility, an investigation would not serve the interests of justice, and the Chamber rejected the prosecution's application. The reason is that the time between the occurrence of the crime and the investigation application is too long and the complicated changes in the domestic political situation in Afghanistan will make it difficult for prosecutors to obtain cooperation and will find it difficult to investigate and prosecute. This, far from honoring the victims' wishes and aspiration that justice be done, would result in creating frustration and possibly hostility vis-a-vis the Court and therefore negatively impact its very ability to pursue credibly the objectives it was created to serve [1]. In fact, in order to avoid the trial of the ICC, the United States has resorted to excessive constraints. The most typical one is that on September 10, 2018, National Security Advisor John Bolton announced a number of hostile policies aimed at the ICC. It mentioned that if the ICC initiates a war crimes allegations, the U. S. government will impose sanctions on the court, including prohibiting judges and prosecutors of the ICC from entering the U. S.; sanctioning their funds in the U. S. financial system and prosecuting them in the U. S. criminal system; the 
U. S. will also consider passing the United Nations The Security Council comes to restrict the court's powers and so on. On the same day, the White House issued a similar statement entitled "Protecting American Constitutionalism and Sovereignty from the International Criminal Court [2]," and the international community was in an uproar.

In fact, as early as 2007, the Office of the Prosecutor of the ICC began a preliminary review of suspected international crimes committed by American soldiers during the Afghanistan War. In the 2014 report of the Office of the Prosecutor of the ICC, it detailed the clues it obtained indicating that between May 2003 and June 2004, the US military in Afghanistan used "enhanced interrogation techniques" on detainees, which specifically include food deprivation, deprivation of clothing, environmental manipulation, sleep adjustment, use of individual fears, use of stress positions, sensory deprivation (deprivation of light and sound), sensory overstimulation and even severe beating, especially beating on the soles of the feet, suspension by the wrists, and threats to shoot or kill. The severity and duration of the use of this technology has constituted inhumane treatment, torture, or insult to personal dignity in the sense of international law [3]. On November 20, 2017, the Office of the Prosecutor issued an official statement entitled "The Prosecutor of the International Criminal Court, Fatou Bensouda, requests judicial authorisation to commence an investigation into the Situation in the Islamic Republic of Afghanistan", formally requested authorisation from the Court's Judges to initiate an investigation into alleged war crimes and crimes against humanity, committed in the context of the ongoing armed conflict in the Islamic Republic of Afghanistan. The statement mentioned that there are reasonable grounds to believe that there are war crimes committed by members of the United States armed forces on the territory of Afghanistan, and by members of the US Central Intelligence Agency in secret detention facilities in Afghanistan and on the territory of other States Parties to the Rome Statute, principally in the period of 2003-2004 [4].

As we all know, the United States' attitude towards the ICC has always been negative and confrontational. As early as the Clinton government, the United States voted against the establishment of the ICC at the Rome Conference. In August 2002, Bush signed the American Service-Members' Protection Act to prohibit any cooperation with the ICC and even authorize the use of all necessary and appropriate means to bring about the release of any person who is being detained or imprisoned by, on behalf of, or at the request of the ICC [5]. Scholars in China and abroad have also predicted the emergence of conflicts between the United States and the ICC similar to this incident. For example, some Chinese scholars have predicted: "from the perspective of U.S. global strategy and national interest, applying military force internationally when needed is the underlining premise of the 'policy cores'. These two 'policy cores' and the premise will thus continue to influence the U.S. policy toward the ICC, resulting potentially in new frictions between the U.S. and ICC in the near and long terms, particularly when an emergency event occurs in the global hot spots and when the Aggression Amendments of the Rome Statute takes effect expectedly after 2017 [6]." William A. Schabas also predicted: "to the extent that the Court takes on investigations into situations that are sensitive to the United States, such as Afghanistan, Iraq and Palestine, the storm clouds will surely return [7]."

The situation in Afghanistan is bound to be a stroke of storm since the establishment of the ICC and the trial of the U. S. armed forces in Afghanistan is bound to be difficult. One of the biggest legal obstacles is that the United States has signed a bilateral military status agreement with Afghanistan, granting the U. S. armed forces an exclusive jurisdiction for criminal cases in the territory of Afghanistan. In the situation in Afghanistan, part of the territorial jurisdiction assigned to the ICC in accordance with the Rome Statute signed by Afghanistan overlaps with the jurisdiction in criminal cases assigned to the United States under the Status of Forces Agreement ("SOFA"), and thus conflicts. Analyzing the problem of this kind of jurisdictional conflict and the way to resolve it is not only beneficial between the United States and Afghanistan, but the United States is a signatory to at least more than 100 SOFAs [8]. We should also note that the United Kingdom, France, Australia, Germany, Italy, Russia, Spain, and many other countries have also military abroad and signed similar SOFAs with the host country, and the corresponding host country has a wider scope. Among these host countries, most of them are parties to the Rome Statute of the ICC. In addition, in 2017, China has established the "Chinese People's Liberation Army Support Base in Djibouti" and it is likely to continue to expand the scale of overseas troops in the future, and it is also facing the signing of SOFA and the establishment of "exclusive criminal jurisdiction" for its own armed forces. In terms of the relationship with the ICC, China and the United States have a certain degree of similarity. They are not a signatory to the Rome Statute, and the host country is often a signatory to the Rome Statute. Therefore, clarifying the legal crux of the conflict between the jurisdiction of the stationed country and the jurisdiction of the ICC in the overseas military and providing corresponding solutions are also valuable for China.

\section{The Adjustment of Military Personnel's Criminal Immunity and the Jurisdiction of the ICC}

The first international law issue is whether the ICC has jurisdiction, when the ICC intends to conduct international trials for crimes committed by the United States military. The ICC can exercise jurisdiction over criminal acts committed by a national of a non-state party (that is, soldiers of the US military stationed in Afghanistan in the Afghan situation) in the territory of a state party (that is, the host country, Afghanistan in situation in Afghanistan). This is based on the territorial jurisdiction, which means any country has the right to exercise jurisdiction over foreigners who commit crimes in its territory. State party or declaring states submit their own 
jurisdiction to the ICC by consent. This is an act of transferring part of its judicial power based on its own interests and global interests, and it is a special way of exercising sovereignty. Therefore, the jurisdiction of the ICC over the nationals of non- state party is essentially an extension of the territorial jurisdiction of the state party or non- state party that accept the jurisdiction of the ICC. Therefore, to determine whether the ICC has jurisdiction over the U. S. military in Afghanistan, the fundamental element is to determine whether the host country has jurisdiction over the U. S. military in Afghanistan.

Before discussing the jurisdictional conflicts between the sending state at the treaty law level and the ICC, it is worth pointing out that the sending state at the level of customary international law can also claim criminal jurisdiction over military personnel. This mainly involves the issue of state officials' immunity from foreign criminal jurisdiction. If overseas military can exempt the host country from criminal jurisdiction in terms of their authority, then the ICC will certainly not enjoy jurisdiction over international crimes on the territory of the host country.

Traditionally, international conventions and customary international law have granted the Head of State, the Head of Government and the Minister for Foreign Affairs immunity ratione personae [9]. At the same time, the immunity ratione materiae refers to the Immunity that state officials enjoy in the performance of their duties that can be called "official act" [10]. Based on the concept of immunity ratione materiae, customary international law can divide the behavior of related persons into "act performed in an official capacity" and "act performed in a private capacity" and the immunity ratione materiae is only applicable to the "acts performed in an official capacity" of state officials during their duty time. According to the International Law Commission's report, there are three major elements of immunity in matter: (a) It is granted to all State officials; (b) It is granted only in respect of acts that can be characterized as "acts performed in an official capacity"; (c) It is not time-limited since immunity ratione materiae continues even after the person who enjoys such immunity is no longer an official [11].

Since the immunity ratione materiae can be granted to all state officials, the overseas military is of course the subject of the immunity ratione materiae. immunity ratione materiae also emphasizes "acts performed in an official capacity", that is, only when there is a connection between the state and the actions performed by state officials, can there be grounds for exercising immunity. It is precisely because of this connection that the relevant behavior is the behavior performed on behalf of the state. Therefore, in order to conclude that "there is such a connection," the above behavior must first be attributable to the state. The definition of "sovereignty and exercise of elements of the governmental authority" should be based on two factors, namely: certain activities which, by their nature, are considered to be expressions of or inherent to sovereignty (police, administration of justice, activities of the armed forces, foreign affairs); certain activities occurring during the implementation of State policies and decisions that involve the exercise of sovereignty and are therefore linked to sovereignty in functional terms. Then, because of the close connection with the sovereign element, the overseas military can certainly enjoy the immunity ratione materiae.

In national practice, there are also abundant national court precedents supporting military officers to enjoy criminal immunity in foreign countries, such as the Mario Luiz Lozano case tried by the Criminal Hall, Supreme Court of Cassation of Italy in 2008 [12]; Border Guards Prosecution Case tried by the Federal Supreme Court of Germany on November 3, 1992, concerning a young German who was shot and killed by the border guards of the German Democratic Republic when he tried to cross the so-called Berlin Wall [13]; United States $v$. Noriega judged by the Circuit Court on July 7, 1997, when the plaintiff Noriega was the commander of the Panamanian Armed Forces, he was sued for trafficking in international drugs to the United States [14]. Therefore, all members of the overseas military are entitled to immunity from the host country as long as they are "acts performed in official capacity."

However, this kind of immunity only produces effects in national courts or foreign courts, and does not hinder the jurisdiction of ICC. The first thing to point out is that the enjoyment of criminal immunity does not mean that the relevant sovereign country does not have to bear state responsibility. The immunity is only a procedural interruption and does not affect legal liability in the substantive sense. Meanwhile, the converse is the same. Despite the waiver of immunity for an official, the official's country is not exempt from responsibility for actions taken in an official capacity under international law. As the International Court of Justice stated in the Arrest Warrant case: "Immunity from criminal jurisdiction and individual criminal responsibility are quite separate concepts. While jurisdictional immunity is procedural in nature, criminal responsibility is a question of substantive law. Jurisdictional immunity may well bar prosecution for a certain period or for certain offences; it cannot exonerate the person to whom it applies from all criminal responsibility [15]." More importantly, the foreign criminal jurisdiction immunity of state officials cannot be invoked in ICC. This has already gained a considerable degree of international consensus. The ICC, the International Tribunal for the Former Yugoslavia and the Special Court for Sierra Leone all ruled that the immunity of state officials from foreign criminal jurisdiction does not apply in these courts [16]. Article 27, paragraph 2 of the Rome Statute also states more clearly: "Immunities or special procedural rules which may attach to the official capacity of a person, whether under national or international law, shall not bar the Court from exercising its jurisdiction over such a person."

To take a step back, even at the level of national courts, it is difficult to apply statutory immunity to international crimes, especially jus cogens crimes under the jurisdiction of the ICC. In this regard, many scholars believe that it has become customary international law [17]. The jurisprudence of domestic courts and the International Law Commission also support this view [18]. The International Law Commission 
considers that the international crimes that do not apply subject matter immunity include the following: Genocide, crimes against humanity, war crimes, torture and enforced disappearances. In the activities of overseas military stationing, the above-mentioned six international crimes are likely to occur. Article 23 of the draft conclusions of the International Law Commission on the Peremptory norms of general international law (jus cogens) also clearly pointed out that Immunity ratione materiae shall not apply to any offence prohibited by a peremptory norm of general international law (jus cogens). At the same time, the national practice that supports jus cogens crimes constitute an exception to the Immunity ratione materiae is extensive, such as Attorney-General of the Government of Israel v. Eichmann (Israel) [19], Bouterse case (Netherlands) [20], Guatemala genocide case (Spain) [21], Scilingo Manzorro (Alolfo Francisco) v. Spain (Spain) [22], etc. Perhaps the most relevant case is the Pinochet case in the United Kingdom. In this case, Lord Brown-Wilkinson, Lord Hope, and Lord Phillips all emphasized in their opinions that Immunity ratione materiae does not apply to international crimes of a jus cogens nature [23].

Therefore, not only the relevant international courts, the Rome Statute and judicial practice have made it clear that the Immunity ratione materiae from criminal jurisdiction of overseas military personnel cannot be applied to the crimes of jus cogens, but the national court level has also formed similar customs. Therefore, military personnel's Immunity ratione materiae has already been adjusted to the jurisdiction of the ICC, thus there is no conflict exists.

\section{The Jurisdiction Conflict Between the SOFA and the ICC}

The Immunity ratione materiae from criminal jurisdiction in the dimension of customary international law cannot be a reason for exemption from the jurisdiction of the ICC for international crimes committed by overseas military personnel, but the SOFA, a bilateral treaty that exists widely in the activities of overseas military, is much more complicated. Since it has become a trend to stipulate the exclusive criminal jurisdiction of the sending states in the SOFA, the host country often has no jurisdiction over criminal crimes committed by overseas military personnel on its territory, which has caused a substantial conflict with the jurisdiction of the ICC.

As early as January 2002, the North Atlantic Treaty Organization ("NATO")-led international peacekeeping force in Afghanistan had reached a bilateral agreement with Afghanistan, giving the United States exclusive jurisdiction over criminal and disciplinary cases on the territory of Afghanistan [24]. Between 2002 and 2003, the United States also entered into a series of corresponding Status of Forces Agreements with Afghanistan, which came into force in May 2003 [25]. After Obama took office, the U. S. military in Afghanistan and the International Security Assistance Force in Afghanistan under the leadership of NATO began to withdraw armed forces from Afghanistan in phases since July 2011. Most of the overseas military personnel have been withdrawn by the end of 2014. At the same time, it transferred security and defense to the Afghan National Army and successively signed the "Strategic Partnership Agreement" (May 2012) and the "Bilateral Security Agreement" (November 2013) with Afghanistan. On September 30, 2014, the United States and Afghanistan signed the "Security and Defense Cooperation Agreement" in Kabul, the capital of Afghanistan. The first paragraph of Article 13 of the agreement once again clearly stipulates that "Afghanistan therefore agrees that the United States shall have the exclusive right to exercise jurisdiction over such persons in respect of any criminal or civil offenses committed in the territory of Afghanistan. Afghanistan authorizes the United States to hold trial in such cases, or take other disciplinary action, as appropriate, in the territory of Afghanistan [26]." It should be noted that what the United States has extensively implemented in the post-Cold War period is the exclusive jurisdiction of overseas military. This is also the jurisdiction strategy that the United States is still trying to promote until now. For example, in the 1996 "Agreement on Military Exchanges and Visits Between the Government of the United States of America and the Government of Mongolia", Article 10 of the Agreement stipulates: "United States military authorities shall have the right to exercise within Mongolia all criminal and disciplinary jurisdiction over United States [p]ersonnel conferred on them by the military laws of the United States. Any criminal offenses against the laws of Mongolia committed by a member of the U. S. forces shall be referred to appropriate United States authorities for investigation and disposition". The agreement allows the Mongolian government to require the United States to waive its jurisdiction in the case of alleged crimes that are not related to official duties, but at this time the United States has no obligation to waive jurisdiction and only gives "appropriate consideration" to any such request.

From this point of view, in the situation in Afghanistan, the so-called exclusive jurisdiction of the United States stipulated in the bilateral agreement conflicts with the jurisdiction of the ICC. The bilateral treaty between the United States and Afghanistan has restricted the jurisdiction of American citizens in Afghanistan's territorial jurisdiction. As a result, in theory, Afghanistan, which is a party to the Rome Statute, will face a dilemma if it wants to refer its territorial jurisdiction to the ICC.

\section{Ideas for Resolving the Conflict of Jurisdiction Between the SOFA and the ICC}

There is a view that for war crimes, which is one of the most serious international crimes and is regulated by jus cogens, any country may exercise universal jurisdiction over it and it's has already become a rule of customary international law [27]. Accordingly, the ICC can directly exercise jurisdiction in the situation in Afghanistan. In terms of war crimes, the 1949 
Geneva Conventions with 196 state parties stipulate that the contracting parties are obliged to "enact any legislation necessary and "provide effective penal sanctions" for "any of the grave breaches of the present Convention". It is also obliged to "search for persons alleged to have committed, or to have ordered to be committed, such grave breaches, and shall bring such persons, regardless of their nationality, before its own courts" [28]. Moreover, in terms of quantity and geographical distribution, it is common for the state to exercise criminal jurisdiction over crimes against humanity, war crimes, genocide, torture and other prohibited acts that constitute jus cogens. If all countries in the world are obliged to enforce universal jurisdiction over war crimes, even according to the delegated jurisdiction theory, when the prosecutor begins to investigate a crime in accordance with Article 13 (3) of the Rome Statute, the ICC can be actually authorized by any state party with universal jurisdiction over war crimes.

However, the author believes that this view is untenable. In the Armed Activities on the Territory of the Congo case, the Democratic Republic of the Congo tried to prove that the International Court of Justice ("ICJ") has jurisdiction on the basis that the relevant suspected violations constituted violations of the jus cogens, that is, despite Rwanda did not agree to accept the jurisdiction of the ICJ in accordance with the requirements of the Statute of the ICJ, the ICJ still has jurisdiction. However, the ICJ pointed out that "a norm having such character may be at issue in a dispute cannot in itself provide a basis for the Court's jurisdiction to entertain that dispute - Court's jurisdiction always based on consent of the parties [29]." The ICJ also reiterated this principle in the application of Application of the Convention on the Prevention and Punishment of the Crime of Genocide case [30]. In fact, during the contracting process of the Rome Statute, some delegations such as Germany and South Korea proposed that a supranational jurisdiction based on universal jurisdiction should be established, but they met with widespread opposition. This, of course, is largely due to the consideration of national sovereignty, and the product of a compromise that was eventually formed, that is, Article 12 of the Rome Statute is ultimately based on the consent of the state party. Therefore, the aforementioned view itself conflicts with the provisions of the Rome Statute and is difficult to establish.

From the author's point of view, there are at least two possible solutions to the problem of conflict of jurisdiction in the situation in Afghanistan: First, the conflict can be eliminated through the interpretation of the treaty. As mentioned above, the "Status of Garrison Agreement" provides for exclusive jurisdiction over "criminal cases." Then, how to interpret the connotation and extension of the "criminal" cases here? Does it only include criminal cases in the sense of domestic law, or include both domestic and international criminal crimes? According to the provisions of Article 31 of the Vienna Convention on the Law of Treaties ("VCLT"), a treaty shall be interpreted in good faith in accordance with the ordinary meaning to be given to the terms of the treaty in their context and in the light of its object and purpose. This article means that the treaty interpretation rules in the Convention include three methods: the first method is an interpretation in good faith, the second method is a literal interpretation method, and the third is a context interpretation method. First of all, it is difficult to draw an exact conclusion from the pure literal meaning, and the word "criminal" is not modified with a clear attribute. From a contextual perspective, the expression used in the SOFA signed by the international peacekeeping forces and Afghanistan is "criminal or disciplinary offences." The US-Afghanistan SOFA that took effect in May 2003, in which the expression "authorizes the US Government to exercise criminal jurisdiction" is used. The expression in the 2014 Security and Defense Cooperation Agreement is "criminal or civil offences". Judging from the expression of these clauses, the SOFA either juxtaposes criminal cases with administrative offences or juxtaposes with civil offences. From the formal logic, or represents the parallel relationship, and if the two sets of concepts here are to satisfy the parallel relationship, they must conform to the existence of the same level of the concept belonging to the same genus concept. However, war crimes that are not stipulated in Afghanistan's domestic criminal law, as the most serious international crimes, are obviously not at the same level as Afghanistan's domestic administrative offences and civil offences. Therefore, from the context, the exclusive jurisdiction enjoyed by the United States in the SOFA should be limited to criminal offences in the sense of Afghanistan's domestic law.

From the principle of good faith interpretation of treaties, although the connotation of "good faith" in international law is abstract and chaotic, it should at least conform to "absence of any intent to defraud or act maliciously" [31]. The signing of the US-Afghanistan bilateral SOFA is very special, and it is less than a year after Afghanistan joined the Rome Statute. If the interpretation of the agreement is that the criminality in the agreement contains international criminal crimes, it means that the purpose of the agreement signed by the United States is to make the United States avoid the jurisdiction of the Rome Statute. Specifically, the fraudulent intent or the intent to seek unreasonable benefits here lies in the fact that the United States uses its dominant position to force Afghanistan to assume national responsibility for violating the Rome Statute and therefore eliminates the possibility of its military personnel being under the jurisdiction of the ICC so that these military personnel can escape the criminal responsibility of international crimes of jus cogens. Obviously, such an interpretation cannot satisfy the "good faith principle" of treaty interpretation.

Second, the maxim lex specialis derogate legi generali. The maxim lex specialis derogate legi generali is a generally accepted technique of interpretation and conflict resolution in international law. It means that whenever two or more norms involve the same case-related matter, priority should be given to the more specific norm. This principle can be applied to several situations: between the various clauses of a single treaty, between the clauses of two or more treaties, between a 
treaty and a non-treaty standard, and between two non-treaty standards [32]. The justification for lex specialis to take precedence over legi generali is that these laws are more specific and usually take into account the characteristics of the situation better than any applicable general law. Its application can usually produce fairer results, and it usually better reflects the intentions of legal subjects. The identification of special laws generally requires specific analysis of specific issues and contextual appreciation, and cannot give a unified conclusion.

And the "self-contained regime" is a typical lex specialis. The so-called "self-contained system" in international law is essentially a lex specialis relative to the general international law rule. The United Nations International Law Commission believes that a self-contained regime refers to a series of interrelated rules and management measures for a combination of rules, including the establishment, interpretation, application, modification or termination of these rules in the research report of "Fragmentation of International Law". The report also pointed out that international human rights law, international humanitarian law and other regulatory systems are typical self-contained regime. For the ICC, as an ICC closely related to international human rights law and international humanitarian law, there is no doubt that it constitutes a self-sufficient system. Moreover, as the Appeals Chamber of the International Criminal Tribunal for the former Yugoslavia stated in the Tadic case: "In international law, every tribunal is a self-contained system [33]." A large number of experts and scholars have also recognized or demonstrated that the ICC conforms to the self-contained system [34].

Specifically, first of all, in terms of internal priority, the ICC, which exists as a self-contained system, has clear requirements on the order in which the rules of international law are applied. Article 21 of the Rome Statute puts the Rome Statute first in the applicable law, and other general rules and principles of international law in the second. In terms of external priority, for example, in the 1999 Waite and Kennedy v. Germany case, the European Court of Human Rights pointed out that member states cannot grant international organizations immunity from litigation procedures, if such immunity would endanger the basic human rights guaranteed by the Convention. In this case, the European Court of Human Rights did not mention too much the immunity rules of international organizations, but focused on the state's responsibility to protect basic human rights, pointing out that this responsibility was not affected by any treaty law rules dealing with the relationship between conflicting treaties [35]. Another example is Article 103 of the Charter of the United Nations: "In the event of a conflict between the obligations of the Members of the United Nations under the present Charter and their obligations under any other international agreement, their obligations under the present Charter shall prevail." Although the Rome Statute of the ICC does not contain provisions to resolve conflicts of treaties, based on the axioms of international law that lex specialis as a self-contained system is superior to legi generali and the nature of war crimes as the jus cogens, the author believes that the Rome
Statute should be superior to the SOFA.

\section{The Admissibility Dilemma of the ICC After the United States Prosecuted Itself}

As discussed above, based on treaty interpretation and treaty conflict methods, we can conclude that the ICC has jurisdiction. However, regardless of the outcome of the treaty conflict, the United States may still rely on personal jurisdiction to enjoy the jurisdiction in the sense of domestic law. Even if it loses its exclusive jurisdiction based on the SOFA, it can still sue on its own and is in compliance with Article 19.2 (b) of the Rome Statute which can challenge the jurisdiction of the Court or the admissibility of a case if a State which has jurisdiction over a case, on the ground that it is investigating or prosecuting the case or has investigated or prosecuted.

The preamble of the Rome Statute clearly emphasizes that the ICC established under this Statute shall be complementary to national criminal jurisdictions. Meanwhile, Article 1 of the Rome Statute stipulates that the Court shall be complementary to national criminal jurisdictions and the direct manifestation of this complementary jurisdiction is the issue of admissibility under Article 17. "Jurisdiction" refers to the question of which crimes the ICC has power to deal with. It is a static view of which crimes the ICC has the power to rule on, and it solves the question of whether jurisdiction exists or not, but "admissibility" refers to the question of whether the ICC has the power to rule on specific situations or cases. It is a dynamic perspective to see which situations or cases the ICC has the power to rule on. It is to solve the problem of the exercise of jurisdiction. Therefore, the "admissibility" can also be classified as a broad jurisdictional issue. In order to embody the principle of complementarity of the jurisdiction of the ICC, only when the State with jurisdiction over the case is "unwilling or unable genuinely to carry out the investigation or prosecution", can the ICC initiate proceedings. Regarding "unwillingness", the Rome Statute stipulates a comprehensive set of standards to test it. Article 17 (2) of the Rome Statute stipulates that the court shall consider whether the domestic procedure has been or is in progress in accordance with the principles of due process recognized by international law, whether there has been an unjustified delay, whether the proceedings were not or are not being conducted independently or impartially and this delay or method is inconsistent with an intent to bring the person concerned to justice. Regarding the country's "inability" to conduct investigations and prosecutions, the main consideration is due to a total or substantial collapse or unavailability of its national judicial system, whether the State is unable to obtain the accused or the necessary evidence and testimony or otherwise unable to carry out its proceedings.

In the situation in Afghanistan, once the United States initiates domestic judicial procedures to investigate or prosecute, it will be difficult for the ICC to pass the test of 
admissibility. It is obvious that the domestic judicial system of the United States does not conform to the situation of "inability" to investigate and prosecute, and the determination of "unwillingness" is also difficult. First of all, the domestic judicial purpose of shielding the person concerned from criminal responsibility for crimes mentioned in Article 17.2 (a) of the Rome Statute is a purely subjective standard. Prosecutors are faced with difficulties in searching evidence and can only objectively test whether judicial procedures are effective. What's more, even if the U. S. ultimately refuses to prosecute soldiers and intelligence personnel after investigation, or a verdict of innocence and lightness is reached after the trial, the ICC cannot infer its purpose of shielding from the results alone.

As for Article 17.2 (b), "there has been an unjustified delay in the proceedings which in the circumstances is inconsistent with an intent to bring the person concerned to justice", there is a precedent in the situation in Libyan. In the Prosecutor $v$. Saif Al-Islam Gaddafi and Abdullah Al-Senussi, when determining whether the proceedings against Al-Senussi were delayed, the Chamber considered the date of the case moved from one stage to another, the date of the witness interview, and the facts of the allegations and concluded that "a period of less than 18 months between the commencement of the investigation in relation to $\mathrm{Mr} \mathrm{Al}-\mathrm{Senussi}$ and the referral of the case against him to the Accusation Chamber cannot be considered to constitute an unjustified delay inconsistent with an intent to bring Mr Al-Senussi to justice" [36]. Although there is only a case identification rather than a unified standard, it can be seen that the ICC's judgment of "unjustified delay" can generally be judged from the length of time and the complexity of the facts because the determination of " unjustified delay" needs to be combined with the circumstances of the specific case. However, it should not be overlooked that even if there is an "unjustified delay", the United States still has the right to provide reasonable reasons to defend against it.

The last Article 17.2 (c) concerning the independence and impartiality of the domestic judicial proceeding are also issues beyond the reach of the ICC. The International Criminal Tribunal for the former Yugoslavia had discussed the independence of judges, which basically focused on conventional circumstances such as whether the judge has economic interests related to the case [37]. However, there is no reference to this special case involving the national interests of the United States and the requirement of justice is highly compatible with the subjective elements in Article 17.2 (a) and Article 17.2 (b). It is a re-declaration of the synonymous requirement, and it is still difficult to escape the identification dilemma at the practical level.

On the whole, the United States prosecutes criminal suspects through domestic judicial organs, making the ICC unable to pass the test of admissibility, and can exclude the jurisdiction of the ICC. At present, it is the most well-founded and fastest way to evade. Of course, it is relatively difficult for ICC to prove whether there are circumstances of "purpose of shielding", "unjustified delay" and "independence and impartiality" in U.S. court trials. In addition, the precedent of the United States tells us that it is not groundless to predict the existence of "shielding" in US court trials. For example, during the Vietnam War, on March 16, 1968, a platoon commanded by U. S. Army Lieutenant William Calley killed 150 civilians in My Lai Village in Vietnam, causing the world shocking "My Lai Massacre", but he was released on parole after only three years in prison. On November 9, 2005, U. S. soldiers in Iraq killed 24 civilians in the town of Haditha. However, in the end, the US military personnel involved in the case were tried in the US military court. Seven of them were acquitted and one was sentenced to 90 days' imprisonment without execution. Of course, the U. S. evading the jurisdiction of the ICC through independent investigations and prosecutions is not necessarily a negative effect, but we hope that the United States can make a fair judgment on the suspects involved in the case. In this way, it is not impossible for the ICC to retreat and achieve justice. There are different ways to achieve justice, but if the result of justice can be achieved, it is also in line with the purpose of the ICC.

\section{Conclusion}

To sum up, there are at least the two legal difficulties mentioned above for the ICC to finally investigate, prosecute and even try the American soldiers who committed war crimes on the territory of Afghanistan. At present, the essence of the conflict of jurisdiction can be attributed to the issue of conflict of treaties between different state parties but the VCLT has no explicit text on this issue. after entering the stage of prosecution, it is difficult to predict where the ICC will start to resolve such conflicts. On the macro level, if the situation in Afghanistan can finally enter the prosecution and trial stage, it will be of great significance to the ICC. On the one hand, African countries are generally dissatisfied that the ICC only judges African leaders and ignores the crimes of Western countries. As early as 2012, the ICC sued President Uhuru Kenyatta and Deputy President William Ruto of Kenyan for crimes against humanity, which provoked collective opposition from African countries. During the 25th African Union Summit in 2015, because the ICC required South Africa to arrest Sudan President Al-Bashir who participated in the summit, it was again protested by the Sudanese government, the African Union and the South African government, the host country of the summit. The President of Zimbabwe is reported to have told the UN General Assembly that the ICC has no credibility in Africa. He said, "The Court seems to exist only for alleged offenders of the developing world, the majority of them Africans. The leaders of the powerful Western States guilty of international crime, like Bush and Blair, are routinely given the blind eye. Such selective justice has eroded the credibility of the ICC on the African continent [38]." If the political pressure in this situation in Afghanistan can be broken down to thoroughly investigate and prosecute the war crimes of the US military, it will be of great value for the ICC to regain the trust of African countries and other countries with similar positions. On the 
other hand, as to how to resolve the conflict between the bilateral treaty that excludes the jurisdiction of the ICC, this is another excellent opportunity for the ICC to interpret the Rome Statute and resolve the conflict of treaties, especially in international law. It has a positive effect on the progress and development of international criminal law.

\section{References}

[1] ICC Pre-Trial Chamber II, Decision Pursuant to Article 15 of the Rome Statute on the Authorisation of an Investigation into the Situation in the Islamic Republic of Afghanistan, ICC-02/17-33, 12 April 2019.

[2] The White House, National Security \& Defense: "Protecting American Constitutionalism and Sovereignty from the International Criminal Court", 10 September 2018 $<$ https://www.whitehouse.gov/briefings-statements/protectingamerican-constitutionalism-sovereignty-international-criminal -court> accessed 30 May 2019.

[3] ICC Office of the Prosecutor, Report on Preliminary Examination Activities 2014, 2 December 2014, para. 94.

[4] ICC: "The Prosecutor of the International Criminal Court, Fatou Bensouda, requests judicial authorisation to commence an investigation into the Situation in the Islamic Republic of Afghanistan"

$<$ https://www.icc-cpi.int//Pages/item.aspx?name=171120-otpstat-afgh $>$ accessed 11 July 2020.

[5] See SEC. 2008. 22 U. S. C. 7427 of American Service members' Protection Act Of 2002 < https://legcounsel.house.gov/Comps/aspa02.pdf >accessed 30 July 2020.

[6] Hao, Jia. (2011). On U. S. Policy Toward the International Criminal Court. American Studies Quarterly, 25 (4), 45. (in Chinese)

[7] William A. Schabas, An introduction to the International Criminal Court, 4th ed., Cambridge: Cambridge University Press, 2011, p. 30. doi: 10.1017/CBO9780511975035

[8] R. Chuck Mason, "Status of Forces Agreement (SOFA): What Is It, and How Has It Been Utilized?", CRS Report for Congress, $\quad 15 \quad$ March 2012 $<$ https://fas.org/sgp/crs/natsec/RL34531.pdf >accessed 29 May 2020 .

[9] See the judgment of 14 February 2002 in Arrest Warrant of 11 April 2000 (Democratic Republic of Congo v. Belgium), Judgment, I. C. J. Reports 2002, para. 51.

[10] UN Doc. A/CN.4/661, para. 53.

[11] UN Doc. A/CN.4/686, para. 17.

[12] Mario Luiz Lozano case, Corte Suprema di Cassazione, Sala Penale (Italy), judgement of 24 July 2008.

[13] Border Guards case, Federal Criminal Court of Germany, decision of 3 November 1992 (case No. 5 StR 370/92).

[14] United States v. Noriega, 117 F.3d 1206 (11th Cir. 1997).

[15] Arrest Warrant of 11 April 2000 (Democratic Republic of the Congo v. Belgium), Judgment, I. C. J. Reports 2002, p25.
[16] Sarah Williams, Hybrid and Internationalised Criminal Tribunals - Selected Jurisdictional Issues, Oxford: Hart Publishing, 2012, pp. 58-133. doi: 10.5040/9781472565938

[17] Ramona Pedretti, Immunity of heads of state and state officials for international crimes, Leiden: Martinus Nijhoff Publishers, 2014, pp. 57-98. doi: 10.1163/9789004287778

[18] UN Doc. A/CN.4/701, para. 189.

[19] Israel, Attorney-General of the Government of Israel v. Eichmann, Judgment of the Supreme Court, English translation available in available in International Law Reports, vol. 36 (1968), p. 277.

[20] Netherlands, Bouterse, Judgment of the Supreme Court of 18 September 2001.

[21] Spain, Guatemala Genocide, Menchú Tumm and Others v. Two Guatemalan Government Officials and Six Members of the Guatemalan Military, Judgment of the Constitutional Court of 26 September 2005.

[22] Spain, Scilingo Manzorro (Alolfo Francisco) v. Spain, Judgment of the Supreme Court of 1 October 2007.

[23] United Kingdom, R v. Bartle and the Commissioner of Police for the Police and Others, Ex Parte Pinochet, Judgment of the House of Lords of 24 March 1999, reproduced in International Legal Materials, vol. 38 (1999).

[24] See Military Technical Agreement Between the International Security Assistance Force and the Interim Administration of Afghanistan

$<$ http://webarchive.nationalarchives.gov.uk/+/http:/www.opera tions.mod.uk/isafmta.pdf $>$ accessed 30 May 2019.

[25] Agreement regarding the Status of United States Military and Civilian Personnel of the U. S. Department of Defense Present in Afghanistan in connection with Cooperative Efforts in Response to Terrorism, Humanitarian and Civic Assistance, military training and exercises, and other activities. Exchange of notes 26 September and 12 December 2002 and 28 May 2003. Entered into force 28 May 2003.

[26] See "Security and Defense Cooperation Agreement between the United States and the Islamic Republic of Afghanistan" $<\mathrm{http} / /$ staging.afghanembassy.us/contents/2016/04/documents /Bilateral-Security-Agreement.pdf> accessed 30 May 2020.

[27] Bassiouni, M. (2001). Universal jurisdiction for international crimes: Historical perspectives and contemporary practice. Virginia Journal of International Law, 42 (1), 81.

[28] See Article 49 of the First Geneva Convention "for the Amelioration of the Condition of the Wounded and Sick in Armed Forces in the Field"; Article 50 of the Second Geneva Convention "for the Amelioration of the Condition of Wounded, Sick and Shipwrecked Members of Armed Forces at Sea"; Article 129 of the Third Geneva Convention "relative to the Treatment of Prisoners of War"; Article 146 of the Fourth Geneva Convention "relative to the Protection of Civilian Persons in Time of War".

[29] Armed Activities on the Territory of the Congo (New Application: 2002) (Democratic Republic of the Congo v. Rwanda), Jurisdiction and Admissibility, Judgment, I. C. J. Reports 2006, p. 6.

[30] Application of the Convention on the Prevention and Punishment of the Crime of Genocide (Croatia v Serbia), Judgment, I. C. J. Reports 2015, p. 3. 
[31] Bryan A. Garner and Henry C. Black, Black's law dictionary, 7th ed., Saint Paul, MN: West Group, 1999, p. 701.

[32] Yearbook of the International Law Commission 2006, Volume II (Part Two), Chapter XII, p178.

[33] ICTY Appeals Chamber, Prosecutor v. Dušan Tadić, No. IT-94-1-T, Decision on the Defence Motion for Interlocutory Appeal on Jurisdiction, 2 October 1995, para. 11.

[34] Kreb, C. (1998). Penalties, enforcement and cooperation in the international criminal court statute (parts vii, ix, x). European Journal of Crime, Criminal Law and Criminal Justice, 6 (4), 450 .

[35] Waite and Kennedy v. Germany case, 26083/94, ECHR, February 1999
[36] Prosecutor v. Saif Al-Islam Gaddafi and Abdullah Al-Senussi, ICC-01/11-01/11-466-Red, Decision on the Admissibility of the Case against Abdullah Al-Senussi, Pre-Trial Chamber I, 11 October 2013, paras 227-229.

[37] Prosecutor v. Anto Furundzija, IT-95-17/1-A, Judgement, Appeals Chamber, 21 July 2000, para 189.

[38] See "Mugabe Slams "Blind" International Criminal Court" (23rd September 2011) The Zimbabwe Mail $<$ http://www.thezimbabwemail.com/zimbabwe/9132-mugabeslams-blind-international-criminal-court.html $>$ accessed 10th July 2020. 